\title{
KESEPAKATAN TERHADAP BRAND WONDERFUL INDONESIA: KAJIAN TERHADAP PELANCONG DAN PEGAWAI PEMERINTAH
}

\author{
Diah Febrina
}

Fakultas Ilmu Komunikasi Universitas Pancasila; diahfebrina@univpancasila.ac.id

\begin{abstract}
ABSTRAK
Kajian ini bertujuan untuk mengkaji kesepakatan dalam strategi pemasaran pariwisata Visit Indonesia Year melalui brand Wonderful Indonesia. Kajian ini menggunakan teori koorientasi sebagai asas kerangka teori. Sejumlah 204 responden yang terdiri dari 110 pelancong dan 94 pegawai pemerintah di Kementerian Pariwisata dan Ekonomi Kreatif Republik Indonesia telah diwawancara dengan menggunakan satu set kuesioner. Berdasarkan hasil kajian ini didapati bahwa pelancong dan pegawai pemerintah tidak memiliki kesepakatan dalam mempersepsi Indonesia melalui brand Wonderful Indonesia. Akan tetapi, hasil uji perbedaan berdasarkan lima elemen dalam branding Wonderful Indonesia menunjukkan bahwa pelancong dan pegawai pemerintah sepakat masyarakat Indonesia adalah mas yarakat yang ramah.
\end{abstract}

Kata kunci: teori koorientasi, kesepakatan (agreement), brand pariwisata, Wonderful Indonesia

\begin{abstract}
This study aims to review the agreement in the Visit Indonesia Year tourism marketing strategy through the Wonderful Indonesia brand. This study uses the theory of co-orientation as a theoretical framework. A total of 204 respondents consisting of 110 travelers and 94 government employees in the Ministry of Tourism and Creative Economy of the Republic of Indonesia were interviewed using a set of questionnaires. Based on the results of this study it was found that travelers and government employees did not have an agreement in perceiving Indonesia through the Wonderful Indonesia brand. However, the difference test results based on five elements in the Wonderful Indonesia branding show that travelers and government employees agree that the Indonesian people are friendly people.
\end{abstract}

Keywords: cooriation theory, agreement (agreement), tourism brand, Wonderful Indonesia 


\section{PENDAHULUAN}

Pariwisata secara ekonomi telah menjadi sebuah tumpuan untuk dikembangkan. Hal ini karena pariwisata internasional diakui memiliki dampak positif bagi laju pertumbuhan ekonomi melalui berbagai cara dan saluran (Schubert, Brida \& Risso 2011). Visit Indonesia Year merupakan salah satu cara yang dilakukan oleh pemerintah dalam meningkatkan kepariwisataan internasional di Indonesia. Program ini sudah ada sejak tahun 1991 dimana sempat terhenti dan ditumbuhkan kembali pada tahun 2008.

Penumbuhan kembali program ini setelah Indonesia dihantam oleh peristiwa bom Bali 1 dan 2 yang mengakibatkan kemorosatan tajam dalam bisnis pariwisata. Sampai saat ini, program pariwisata melalui Visit Indonesia Year terus dilaksanakan dengan mengusung brand Wonderful Indonesia. Branding Indonesia melalui brand ini merupakan strategi pemasaran Indonesia pada bidang kepariwisataan dengan membawa lima elemen yaitu alam, budayam, keramahan masyarakat, makanan dan nilai keuangan.

Dalam usaha mempromosikan sebuah brand, Wagner \& Peters (2009) mengatakan bahwa komunikasi sebagai salah satu tumpuan dimensi pemasaran memainkan peranan penting untuk para stakeholdernya. Komunikasi dari brand destinasi dapat diinterpretasikan sebagai sebuah proses yang dimulakan dengan sebuah aktivitas oleh pengirim pesan yang biasanya telah secara aktif membangun sebuah brand. Adjouri dan Buttner yang dikutip oleh Wagner \& Peters (2009). mengatakan bahwa dalam sebuah proses komunikasi setiap individu lainnya atau kelompok daripada individu menerima pesan merek. Oleh karena komunikasi ialah sebuah proses di mana informasi tukar menukar, maka kita dapat melihat dampak dari pertukaran informasi ini.

Kajian-kajian terdahulu cukup banyak melihat dampak komunikasi brand melalui pengukuran persepsi terhadap sebuah program branding destinasi. Jetter dan Chen (2011) mengkaji branding dan citra destinasi kota Knoxville sebagai sebuah destinasi konvensi. Persepsi dilihat dari para profesional bidang pariwisata. Selanjutnya Bonn et al. (2005) melihat perbedaan persepsi pelancong internasional dan domestik Amerika Serikat dalam mengunjungi Florida, manakala Ibrahim \& Gill (2005) juga mengukur persepsi konsumen terhadap produk-produk pariwisata di Barbados.

Kesemua kajian di atas melihat persepsi dalam mengukur informasi branding destinasi hanya pada satu pihak yaitu penerima pesan. Manakala pengirim pesan dilihat sebagai individu atau kelompok yang berusaha untuk mengubah persepsi publiknya sesuai dengan yang direncanakannya. Dalam sebuah model komunikasi koorientasi, pengukuran persepsi dapat dilakukan dengan melihat persepsi kedua pihak yaitu pengirim dan penerima pesan. Grunig \& Hunt (1984) mengatakan bahwa dalam twoway symmetric model, pelaku komunikasi tidak hanya mengubah orientasi publik, tetapi mereka juga mencoba mengubah cara organisasi dan publiknya secara bersama berorientasi satu sama lain. Para pengkaji komunikasi telah menciptakan istilah "koorientasi" untuk mendefinisikan orientasi bersama tersebut

Di dalam teori koorientasi, persepsi sebuah program dilihat dari dua sisi. Bagaimana kedua belah pihak mempunyai orientasi yang sama dalam mempersepsi sebuah isu. Koorientasi melibatkan sebuah komitmen di antara individu-individu dan kelompokkelompok untuk mencoba memahami persepsi individu lainnya terhadap realitas dan kegiatan terlepas dari apakah definisi itu diberikan (Taylor \& Kent 2006). Oleh karenanya kajian ini ingin meninjau sejauh mana wujudnya koorientasi antara pelancong dan pegawai pemerintah Indonesia dalam mempersepsi Indonesia melalui brand Wonderful Indonesia. 
Kajian ini bertujuan untuk meninjau kewujudan koorientasi di antara dua kelompok yaitu pelancong dan pegawai pemerintah. Kewujudan tersebut dilihat berdasarkan ada tidaknya kesepakatan antara kedua kelompok dalam mempersepsi Indonesia melalui brand Wonderful Indonesia. Persepsi dua kelompok tersebut adalah persepsi pelancong yang kunjungan Indonesia dan persepsi pegawai pemerintah di Kementerian Pariwisata dan Ekonomi Kreatif Republik Indonesia. Persepsi diukur melalui elemen-elemen dalam brand Wonderful Indonesia yang terdiri dari keindahan alam, budaya Indonesia, keramahan masyarakat, makanan dan nilai keuangan.

\section{METODOLOGI PENELITIAN}

Teori koorientasi yang dikembangkan oleh Jack McLeod dan Steven Chaffee merupakan modifikasi daripada teori ABX Newcomb (Tan 1981). Pendekatan Newcomb terhadap komunikasi adalah pendekatan seorang pakar psikologi sosial berhubungan dengan interaksi manusia. Newcomb beranggapan bahwa di dalam setiap situasi komunikasi, sedikitnya dua individu akan berkomunikasi tentang sesuatu objek atau topik. Sebuah fungsi utama daripada komunikasi adalah untuk membolehkan individu-individu untuk mengatur orientasi secara bersama terhadap satu dengan lainnya dan terhadap sesuatu objek daripada komunikasi. Orientasi adalah bagaimana kita merasakan tentang objek atau individu dan kesadaran kognitif kita terhadap mereka (Tan 1981).

Model koorientasi McLeod dan Chaffee (1973) menghuraikan lebih lanjut bagaimana A dan B memberikan nilai kepada $\mathrm{X}$, objek daripada komunikasi di mana A dan B berorientasi. Koorientasi merujuk kepada sistem saling bergantung daripada interaksi yang menyediakan pengukuran persepsi dan persepsi silang dari dua kesatuan yang berorientasi terhadap satu sama lain dan terhadap beberapa isu. Individu atau kelompok memiliki berbagai tingkat pemahaman dan pendapat tentang hal-hal atau konsep-konsep yang berbeda. Guth \& Marsh (2006) mengatakan bahwa koorientasi dapat menyingkirkan kesalahan besar akibat kesalahfahaman persepsi tentang apa yang dipercayai oleh pihak lain.

Model pengukuran koorientasional yang ditunjukkan pada gambar 1 melakukan pengukuran terhadap kesepakatan, kongruen, dan ketepatan. McLeod dan Chaffee (1973) mendefinisikan kesepakatan sebagai sejauh mana A dan B memiliki penilaian yang sama terhadap X. Ini sering disebut dalam persuasif sebagai "sikap". Manakala Wackman (1973) mendefinisikannya sebagai persamaan di antara dua kognisi individu tentang sebuah objek. Dalam model koorientasi Broom dan Dozier (1990) kesepakatan adalah representasi sejauh mana organisasi dan publik memegang pandangan yang sama terhadap sebuah isu (termasuk definisi dan penilaian mereka terhadap sebuah isu).

Individu A

Individu B
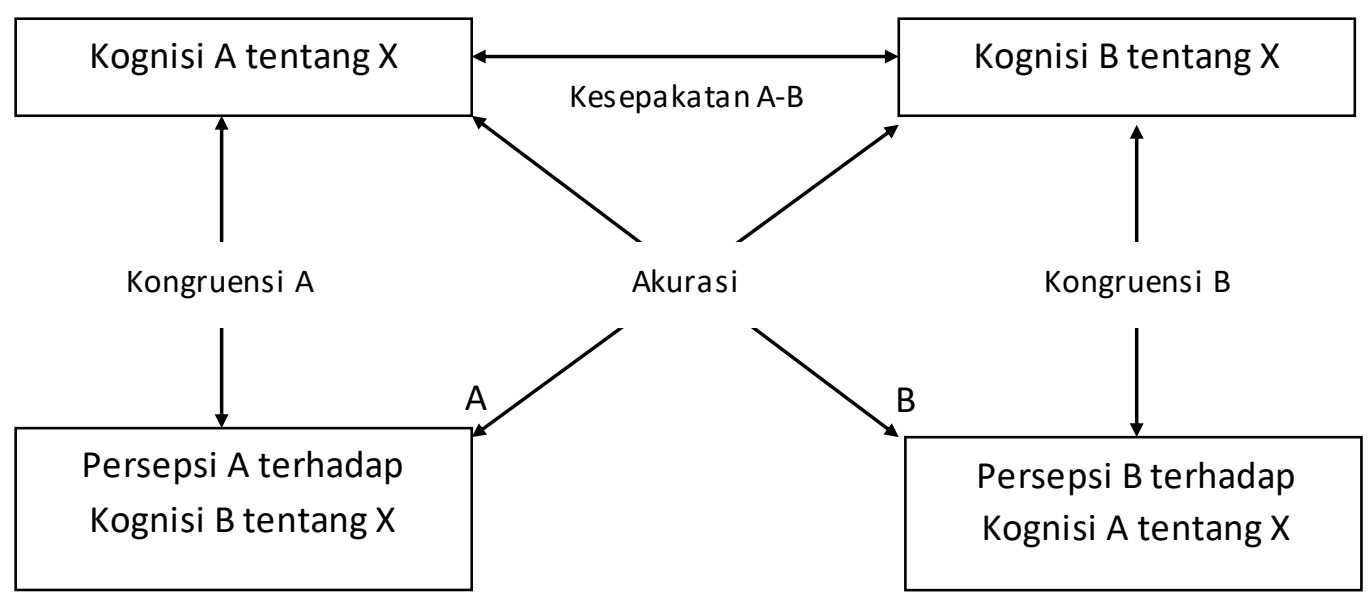

Akurasi

Kongruensi B

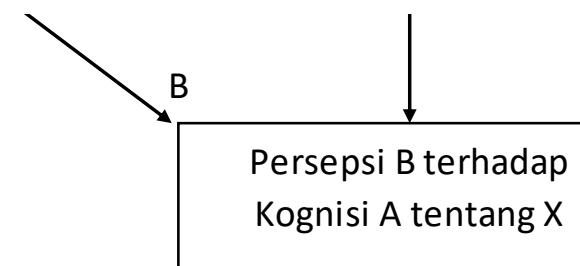


Wackman (1973) menyebut kongruen sebagai kesepakatan yang terlihat (perceived agreement). Dimana ianya ialah persamaan di antara kognisi satu individu tentang objek dan perkiraannya terhadap kognisi individu lain tentang sebuah objek. Manakala McLeod dan Chaffee (1973) mendefinisikan kongruen sebagai tingkat kesamaan di antara kognisi seorang individu dan persepsinya terhadap kognisi individu lainnya. Ini ialah sejauh mana seseorang berfikir individu lain sama ada setuju mahupun tidak setuju terhadapnya mengenai penilaian daripada sebuah objek.

Broom dan Dozier (1990) mengatakan bahwa ketepatan menunjukkan sejauh mana perkiraan satu individu terhadap pandangan individu lainnya ialah sama terhadap pandangan sebenarnya individu lainnya. Manakala McLeod dan Chafee (1973) mendefinisikan ketepatan sebagai sejauh mana perkiraan seseorang cocok dengan pandangan orang lain yang sesuai atau sejauh mana kognisi satu kelompok sama dengan apa yang kelompok lain fikirkan. Selanjutnya Wackman (1973) mendefinisikannya sebagai persamaan di antara perkiraan salah satu individu terhadap kognisi individu lainnya tentang sebuah objek dan kognisi sebenarnya dari individu lainnya tentang sebuah objek. Taylor \& Kent (2006) mengatakan bahwa teori koorientasi mungkin dapat membantu pemerintah dan organisasi untuk mengidentifikasikan dan mengukur isu-isu di mana organisasi dan publik berbeda.

Secara umum teori ini dapat digunakan di banyak bidang. Lariscy \& Kaye (2014), Vercic \& Colic (2016), Walden, Bortree \& DiStaso (2015), Seltzer dan Mitrook (2009) serta Waters (2009) mengaplikasikan teori ini pada bidang public relations. Selain itu, Keunyoung Oh \& Damhors (2009) melakukan penelitian koorientasi dalam persepsi interpersonal pada pasangan suami isteri. Dalam bidang lainnya, model koorientasi digunakan dalam penelitian pembangunan bangsa (Taylor dan Kent 2006), kebijakan penswastaan dan pengkomersialan dalam bidang pertanian (Ajieh et al. 2009) serta Ajieh \& Uzokwe (2014) menggunakan teori ini di komunikasi pembangunan pada bidang pertanian.

Kajian ini menggunakan pendekatan kuantitatif melalui survei terhadap 110 pelancong mancanegara dan 94 pegawai pemerintah di Kementerian Pariwisata dan ekonomi Kreatif Republik Indonesia. Pada penelitian ini sampel dipilih secara bertujuan (purposive sampling). Dalam cara ini pengkaji menentukan responden yang sesuai dengan tujuan kajiannya (Syed Arabi, 2002). Sampel pelancong cirinya adalah pelancong antarabangsa yang datang ke Indonesia minimal satu kali dan akan pulang ke negaranya melalui bandara Soekarno-Hatta. Pelancong yang dipilih berusia serendahrendahnya 20 tahun. Manakala sampel pegawai pemerintah adalah para pegawai di kementerian dengan ciri minimal berpendidikan diploma dan serendah-rendahnya pada peringkat staf.

Pengukuran kesepakatan (agreement) terhadap brand Wonderful Indonesia dalam kajian ini menggunakan adaptasi model koorientasi dari McLeod dan Chaffee (1973). Pengukuran koorientasi pada kajian ini hanya melihat persamaan persepsi antara A dan 
B terhadap X. Persepsi A adalah persepsi pelancong yang datang kunjungan Indonesia dan persepsi B adalah persepsi pegawai Kementerian Pariwisata dan Ekonomi Kreatif Republik Indonesia yang mewakili persepsi pemerintah Indonesia.

Kedua kelompok ini akan mempersepsi Indonesia berdasarkan kepada brand Wonderful Indonesia yang terdiri dari keindahan alam, budaya, keramahan masyarakat, makanan dan nilai keuangan. Selanjutnya akan dilihat kesepakatan antara dua kelompok terhadap perkara tersebut. Walaupun model ini mulanya digunakan untuk pengukuran komunikasi antara manusia, akan tetapi dalam perkembangannya model ini boleh digunakan untuk pengukuran pada peringkat kelompok (Grunig \& Stamm 1973; Broom \& Dozier 1990).

\section{HASIL DAN PEMBAHASAN}

\section{Gambaran Umum Kunjungan Pelancong ke Indonesia}

Tabel.1 memberikan sebuah gambaran mengenai kunjungan pelancong ke Indonesia. Pertama ialah mengenai frekuensi kunjungan ke Indonesia dan Jakarta secara khusus yang dilihat selama 5 tahun terakhir. Hasil menunjukkan frekuensi kunjungan ke Indonesia pada kategori 1-2 kali dan lebih dari 5 kali yaitu masing-masing sebanyak $37 \%$ dan 38\%. Ini bermaksud bahwa ada sebagian pelancong yang sering datang ke Indonesia. Manakala sebagian lagi tidak terlalu sering datang ke Indonesia dan mungkin merupakan kali pertama mengunjungi Indonesia.

Tabel.1 Frekuensi dan destinasi popular

\begin{tabular}{lcc}
\hline & Bilangan & $\%(\%)$ \\
\hline Frekuensi kunjungan ke Indonesia & 41 & 37 \\
1-2 kali & 23 & 21 \\
3-4 kali & 4 & 4 \\
$4-5$ kali & 42 & 38 \\
Lebih dari 5 kali & & \\
& & \\
Destinasi yang sering dikunjungi di Indonesia & 71 & 65 \\
Jakarta & 14 & 13 \\
Bandung & 12 & 11 \\
Bali & 13 & 11 \\
Lainnya & & \\
Frekuensi kunjungan ke Jakarta & & \\
1-2 kali & 54 & 49 \\
3-4 kali & 15 & 14 \\
4-5 kali & 4 & 43 \\
Lebih dari 5 kali & 37 & \\
\hline
\end{tabular}

Secara khusus, pertanyaan selanjutnya ingin mengetahui frekuensi pelancong melawat Jakarta. Berbeda dengan hasil yang ditunjukkan pada soalan frekuensi kunjungan ke Indonesia, sebagian pelancong tidak sering ke Jakarta dalam masa lima tahun terakhir. Mayoritas berada pada kategori kedatangan 1-2 kali yaitu sebanyak 49\%. Kemudian kunjungan lebih dari lima kali sebanyak 33\%, 4-3 kali sebanyak $14 \%$ dan 4-5 kali sebanyak $4 \%$. Selanjutnya tabel.1 menunjukkan tentang destinasi di Indonesia yang 
sering dikunjungi oleh pelancong. Mayoritas pelancong sering berkunjung ke Jakarta (65\%), peringkat kedua ialah Bandung sebanyak

$13 \%$ dan Bali sebanyak 12 $\%$. Oleh kerana kajian ini dilakukan di Jakarta, maka tidaklah mengherankan jika hasil kajian menunjukkan Jakarta sebagai destinasi popular bagi pelancong.

\section{Kesepakatan antara pelancong dan pegawai pemerintah terhadap brand Wonderful Indonesia}

Tabel 2 adalah hasil pengujian dari hipotesis terdapat perbedaan persepsi antara pelancong dan pegawai pemerintah terhadap brand Wonderful Indonesia. Hipotesis ini akan diuji dengan menggunakan ujian t. Hasil kajian pada tabel 2 menunjukkan bahwa keputusan kajian adalah signifikan $(\mathrm{t}=-3.317, \mathrm{df}=202, \mathrm{p}<.05)$. Dapat disimpulkan bahwa terdapat perbedaan persepsi antara pelancong $(\mathrm{M}=3.73)$ dan pegawai pemerintah $(\mathrm{M}=3.91)$ terhadap brand Wonderful Indonesia. Ini bermaksud bahwa tidak adanya kesepakatan antara pelancong dan pegawai pemerintah mengenai merek Wonderful Indonesia.

Tabel 2. Uji perbedaan persepsi antara pelancong dan pegawai pemerintah

\begin{tabular}{lllll}
\hline & $\begin{array}{l}\text { Mean } \\
\text { pelancong }\end{array}$ & $\begin{array}{l}\text { Mean } \\
\text { pegawai } \\
\text { pemerintah }\end{array}$ & $\mathrm{T}$ & $\mathrm{df}$ \\
\hline $\begin{array}{l}\text { Persepsi gabungan terhadap } \\
\text { elemen-elemen brand }\end{array}$ & 3.73 & 3.91 & $-3.317 * 202$ \\
$\begin{array}{l}\text { Wonderful Indonesia } \\
* \mathrm{p}<0.05\end{array}$ & & & &
\end{tabular}

Selanjutnya, kajian ini akan melihat apakah terdapat perbedaan persepsi antara pelancong dan pegawai pemerintah berdasarkan elemen-elemen brand Wonderful Indonesia secara terpisah. Oleh karenanya hipotesis akan terbagi ke dalam 5 sub hipotesis yaitu 1) Terdapat perbedaan persepsi antara pelancong dan pegawai pemerintah terhadap keindahan alam Indonesia. 2) Terdapat perbedaan persepsi antara pelancong dan pegawai pemerintah terhadap budaya Indonesia. 3)Terdapat perbedaan persepsi antara pelancong dan pegawai pemerintah terhadap keramahan masyarakat Indonesia. 4) Terdapat perbedaan persepsi antara pelancong dan pegawai pemerintah terhadap makanan Indonesia. 5) Terdapat perbedaan persepsi antara pelancong dan pegawai pemerintah terhadap nilai wang di Indonesia.

Tabel 3 ialah hasil ujian $t$ untuk sub hipotesis 1 sampai dengan 5. Hasil ujian $t$ untuk hipotesis 1 menunjukkan bahwa keputusan kajian adalah signifikan $(\mathrm{t}=-4.276$, df $=$ $202, \mathrm{p}<.05)$ yaitu terdapat perbedaan persepsi antara pelancong $(\mathrm{M}=3.92)$ dan persepsi pegawai pemerintah $(\mathrm{M}=4.28)$ terhadap keindahan alam Indonesia yang terdiri daripada unsur laut, gunung, pantai dan hutan. Ini bermaksud bahwa tidak adanya kesepakatan antara pelancong dan pegawai pemerintah dalam menilai indahnya alam Indonesia.

Selanjutnya ialah hasil ujian $t$ untuk sub hipotesis 2 yang menunjukkan bahwa keputusan kajian adalah signifikan $(\mathrm{t}=-6.938, \mathrm{df}=202, \mathrm{p}<.05)$. Artinya ialah terdapat perbedaan antara persepsi pelancong $(M=3.83)$ dan pegawai pemerintah $(M=4.35)$ terhadap budaya Indonesia. Ini bermaksud bahwa tidak adanya kesepakatan antara pelancong dan pegawai pemerintah mengenai menariknya budaya Indonesia. 
Tabel 3. Uji perbedaan persepsi antara pelancong dan pegawai pemerintah terhadap alam, budaya, masyarakat, makanan dan nilai keuangan

\begin{tabular}{|c|c|c|c|c|}
\hline & $\begin{array}{l}\text { Mean } \\
\text { pelancong }\end{array}$ & $\begin{array}{l}\text { Mean } \\
\text { pegawai } \\
\text { pemerintah }\end{array}$ & $\mathrm{T}$ & df \\
\hline - H1 : Alam & 3.92 & 4.28 & $-4.276^{*}$ & 202 \\
\hline - $\mathrm{H} 2$ : Budaya & 3.83 & 4.35 & $-6.938 *$ & 202 \\
\hline - H3 : Masyarakat & 4.28 & 4.20 & $0.853^{*}$ & 202 \\
\hline - H4 : Makanan & 3.94 & 4.20 & $-3.090 *$ & 202 \\
\hline - H5 : Nilai keuangan & 2.73 & 2.50 & $2.866^{*}$ & 202 \\
\hline
\end{tabular}

Untuk sub hipotesis 3, hasil ujian $\mathrm{t}$ menunjukkan keputusan kajian yang tidak signifikan $(\mathrm{t}=0.853$, df $=202, \mathrm{p}>.05)$. Keputusan ini merumuskan bahwa tidak terdapat perbedaan antara persepsi pelancong $(M=4.28)$ dan persepsi pegawai pemerintah $(M=4.20)$ terhadap keramahan masyarakat Indonesia. Ini bermaksud bahwa adanya kesepakatan antara pelancong dan pegawai pemerintah mengenai keramahan masyarakat Indonesia.

Manakala hasil ujian $\mathrm{t}$ untuk sub hipotesis 4 menunjukkan bahwa keputusan kajian adalah signifikan $(\mathrm{t}=-3.090, \mathrm{df}=202, \mathrm{p}<.05)$. Artinya adalah terdapat perbedaan persepsi antara pelancong $(M=3.94)$ dan pegawai pemerintah $(M=4.20)$ mengenai makanan Indonesia. Ini bermaksud bahwa tidak adanya kesepakatan antara pelancong dan pemerintah mengenai baiknya makanan Indonesia.

Selanjutnya tabel 6 menunjukkan bahwa keputusan kajian untuk sub hipotesis 5 adalah signifikan $(\mathrm{t}=2.866$, $\mathrm{df}=202, \mathrm{p}<.05)$. Keputusan ini berarti bahwa terdapat perbedaan persepsi antara pelancong $(M=2.73)$ dan pegawai pemerintah $(M=2.50)$ terhadap nilai keuangan di Indonesia. Dapatan ini bermaksud bahwa tidak adanya kesepakatan antara pelancong dan pegawai pemerintah mengenai nilai keuangan di Indonesia.

Pelancong dan pegawai pemerintah tidak memiliki kesepakatan dalam mempersepsi Indonesia melalui brand Wonderful Indonesia. Hal ini berarti, pemerintah belum berhasil mengomunikasikan brand Wonderful Indonesia secara utuh kepada para pelancong. Apabila sebelum membuat brand ini pihak pemerintah menggunakan pendekatan koorientasional untuk mengetahui pendapat dan persepsi publik sasarannya, berbagai informasi awal boleh didapat untuk menghindari perbedaan persepsi ini. Hal ini sesuai dengan pendapat Cutlip et al. (2006) bahwa salah satu tujuan pengukuran koorientasional ialah menyediakan informasi yang diperlukan untuk mengidentifikasi atau menggambarkan suatu perkara.

Broom \& Dozier (1990) mengatakan bahawa model koorientasi dapat digunakan untuk merekomendasikan cara-cara bahwa tujuan simetris dan objektif boleh ditetapkan untuk program komunikasi dan bagaimana dampak dari setiap program dapat dinilai. Model Koorientasi menyarankan bahwa peningkatan dalam ketepatan sebaik peningkatan 
kesepakatan adalah objektif-objektif bermanfaat untuk melanjutkan program komunikasi (Dozier \& Ehling 1992).

\section{PENUTUP}

Dalam bidang public relations, koorientasi diukur untuk mengetahui kesan dari sebuah program. Pengukuran koorientasional ialah pengukuran kesan terhadap sebuah program diukur dari dua sisi yaitu pengirim dan penerima pesan (Broom \& Dozier 1990). Kajian ini melakukan pengukuran untuk mengetahui bagaimana kesan dari komunikasi sebuah brand. Koorientasi pada kajian ini diukur daripada aspek kesepakatan. Kesepakatan ialah sejauh mana kelompok pelancong dan kumpulan pegawai pemerintah memiliki persepsi dan penilaian yang sama terhadap Indonesia melalui branding Wonderful Indonesia.

Kajian menemukan hasil pengukuran daripada kesepakatan tersebut. Hasil kajian menunjukkan bahwa terdapat perbedaan persepsi antara pelancong dan pegawai pemerintah terhadap brand Wonderful Indonesia. Ini bermaksud bahwa tidak terdapat kesepakatan diantara kedua kelompok mengenai Indonesia melalui merek ini. Akan tetapi, ada satu elemen yang menunjukkan bahwa terdapat kesepakatan antara pelancong dan pegawai pemerintah. Pelancong dan pegawai pemerintah memiliki kesepakatan terhadap keramahan masyarakat Indonesia. Ini membuktikan bahwa pemerintah Indonesia telah berhasil mengomunikasikan citra Indonesia sebagai negara yang ramah

Pelancong telah memiliki persepsi yang positif terhadap Indonesia. Persepsi positif pada keindahan alam, budaya, keramahan masyarakat, makanan dan nilai keuangan merupakan sebuah kekuatan Indonesia. Satu perkara menarik yang menjadi perhatian utama ialah mengenai keramahan masyarakat Indonesia. Hasil kajian ini menunjukkan bahwa perkara yang berhubungan dengan keramahan menjadi sebuah nilai bagi Indonesia. Kepopularan Indonesia dari segi keramahannya telah menjadi citra positif bagi Indonesia dan masyarakat Indonesia. Tidak ada salahnya jika pemerintah mulai lebih memperhatikan elemen ini dalam membangun branding pariwisata bagi Indonesia. 


\section{DAFTAR PUSTAKA}

Ajieh P.C, Agwu A.E \& Anyanwu A.C.(2009). Accuracy, Congruency, Agreement between Extension Professionals' and Farmers' Perception of Privatization and Commercialization of Agricultural Extension Services. Agriculturae Conspectus Scientificus 74(2): 115-121.

Ajieh P.C \& Uzokwee. (2014). Effective Application of the Coorientation Communication Model in Disseminating Agricultural Information: A Review. Asian Journal of Agricultural Extension, Economics \& Sociology. 3(3): 217223

Bonn, M.A., Joseph, S.M. \& Dai, Mo. (2005). International Versus Domestic Visitors: An Examination of Destination Image Perception. Journal of Travel Research 43: 294-301.

Broom, G.M. \& Dozier, D.M. (1990). Using Research in Public Relations: Aplication to Program Management. NJ: Prentice-Hall.

Dozier, D.M. \& Ehling, W.P. (1992). Evaluation of Public Relations Programs: What the Literature Tells Us About Their Effects. Dlm. Grunig, J.E. (pnyt). Excellence in Public Relations and Communication Management, hlm. 159184. New Jersey: Lawrence Erlbaum Associates, Inc

Guth, D.W. \& Marsh, C. (2006). Public Relations A Value Driven Approach. Edisi ke3. Boston: Perason Education Inc.

Grunig, J.E. \& Hunt, T. (1984). Managing Public Relations. New York: Holt, Rinehart and Winston The Dryden Press.

Grunig, J.E. \& Stamm, K.R. (1973). Communication and Coorientation of Collectives. American Behavioral Scientist 16(4): 576-590.

Ibrahim, E.E. \& Gill, J. (2005). A Positioning Strategy for A Tourist Destination, Based on Analysis of Customers' Perception and Satisfactions. Marketing Intelligence \& Planning 23(2):172-188.

Jetter, L.G. \& Chen, R.J.C. (2011). Destination Branding and Image: Perceptions and Practices from Tourism Industry Professionals. International Journal of Hospitality \& Tourism 12: 174-187.

Lariscy, R \& Kaye,D. (2010). 489501 Social Media and Shared-or Divergent-Uses? A Coorientation Analysis of Public Relations Practitioners and Journalists Elizabeth Avery School of Advertising and Public Relations. International Journal of Strategic Communication. 4: 189-205

McLeod, J.M. \& Chaffee, S.H. (1973). Interpersonal Approaches to Communication Research. American Behavioral Scientist 16(4): 469-499.

Pappu, R. \& Quester, P. (2010). Country Equity: Conceptualization and Empirical Evidence. International Business Review 19: 276-29.

Schubert, S.F., Brida, J.G. \& Risso, W.A. (2011). The Impact of International Tourism Demand on Economic Growth of Small Economies Dependent on Tourism. Tourism Management 32: 377-385

Seltzer T. \& Mitrook, M. (2009). Two Sides to Every Story: Using Coorientation to Measure Direct and Meta-Perspective of Both Parties in Organization Public relationship. Public relations Journal 3(2): 1-24. 
Syed Arabi, Idid. (2002). Kaedah Penyelidikan Komunikasi dan Sains Sosial. Kuala Lumpur: Dewan Bahasa dan Pustaka.

Tan, A.S. (1981). Mass Communication Theories and Research. Ohio: Grid Publishing, Inc.

Taylor, M. \& Kent, M.L. (2006). Public Relations Theory and Practice in Nation Building. Dlm. Botan, C.H. \& Hazleton, V. (pnyt). Public Relations Theory II, hlm. 341-359. New Jersey: Lawrence Eslbaum Associates, Inc.

Vercic, A.T. \& Colic, V. (2016). Journalist and public relations specialist: A coorientational analysis. Public Relations Review, 42(4): 522-529.

Wackman, D.B. (1973). Interpersonal Communication and Coorientation. American Behavioral Scientist 16(4): 537-550.

Walden, J.A., Bortree, D, \& DiStaso, M. (2015). Reconsidering the public relations professional-blogger relationship: A coorientation study. Public Relations Review. 41(4): 526-532.

Waters, R.D. (2009). Comparing The Two Sides of The Nonprofit Organization-donor Relationship: Applying Coorientation Methodology to Relationship Management. Public Relations Review 35: 144-146 